\title{
Lumen
}

Selected Proceedings from the Canadian Society for Eighteenth-Century Studies

\section{Eighteenth-Century Editions of Virgil's Georgics: From Classical Poem to Agricultural Treatise}

\section{Frans De Bruyn}

Volume 24, 2005

Indigenes and Exoticism

Indigènes et exotisme

URI : https://id.erudit.org/iderudit/1012181ar

DOI : https://doi.org/10.7202/1012181ar

Aller au sommaire du numéro

Éditeur(s)

Canadian Society for Eighteenth-Century Studies / Société canadienne d'étude du dix-huitième siècle

ISSN

1209-3696 (imprimé)

1927-8284 (numérique)

Découvrir la revue

Citer cet article

De Bruyn, F. (2005). Eighteenth-Century Editions of Virgil's Georgics: From Classical Poem to Agricultural Treatise. Lumen, 24, 149-163.

https://doi.org/10.7202/1012181ar

Copyright (c) Canadian Society for Eighteenth-Century Studies / Sociéte canadienne d'étude du dix-huitième siècle, 2005
Ce document est protégé par la loi sur le droit d'auteur. L'utilisation des services d'Érudit (y compris la reproduction) est assujettie à sa politique d'utilisation que vous pouvez consulter en ligne.

https://apropos.erudit.org/fr/usagers/politique-dutilisation/ 


\section{Eighteenth-Century Editions of Virgil's Georgics: From Classical Poem to Agricultural Treatise}

From the time of its initial appearance two thousand years ago, Virgil's Georgics has provoked readers to ask whether or to what extent the poem was intended to impart technical information on the art of husbandry. Seneca's insistence in the first century A.D. that Virgil aimed 'not to teach the farmer, but to please the reader' suggests the question was open to debate and implies the existence of a class of readers who might have been inclined naively to mistake the poet's real purposes. ${ }^{2}$ Yet $\mathrm{Co}-$ lumella, the most comprehensive of the ancient agricultural writers, cites Virgil repeatedly in the twelve books of his Rei Rusticae, crediting the poet as an authority on a number of controverted points. He advises that we should 'pay heed, as to an oracle, to the truest of poets. ${ }^{3}$ The elder Pliny was more critical. He was clearly irked, as L. P. Wilkinson documents, 'by the authority with which less critical minds, awed by the greatness of Virgil's poetry, invested his technical precepts.' Still, as Wilkinson further notes, his view was exceptional. The Georgics shared in the 'supreme reputation enjoyed by the Aeneid and Eclogues throughout classical antiquity. [Virgil] was still to Macrobius "one who was never involved in any scientific error." ${ }^{\prime 4}$

1 The author acknowledges with thanks the financial support of the Social Sciences and Humanities Research Council of Canada, which facilitated the research that contributed to this article.

2 Seneca, 'Epistle 86,' Ad Lucilium Epistulae Morales, trans. Richard M. Gummere, 3 vols. (Cambridge: Harvard University Press, 1962), 2: 319.

3 Columella, Rei Rusticae, 1.4.4: 'si verissimo vati velut oraculo crediderimus.' See Harrison Boyd Ash's translation in the Loeb Classical Library: On Agriculture, 3 vols. (Cambridge, MA: Harvard University Press, 1993), 1:55. On Virgil's reputation in antiquity as an agriculturist, see Wilkinson, The Georgics of Virgil, 270-73.

4 Wilkinson, 272-73. 
The critical consensus of our own time is that the farming precepts in the Georgics, though an important structural element, should be understood as the poem's ostensible theme, a pretext, as it were, for a series of descriptions and meditations about labour, country, and human destiny. ${ }^{5}$ The eighteenth century, by contrast, stands out as a period in the reception history of the Georgics when readers were predisposed to make strong cognitive claims for the poem, not simply as a didactic and instructional document but as a text that conveyed systematic technical and scientific knowledge on matters agricultural. At the same time, it was recognized that such claims were not unproblematic, as Robert Andrews warns in the Preface to his translation of the Georgics. He cautions those who are inclined to read the poem through the prism of their own specialized perspectives,

whether Botany or any branch of Agriculture, Astronomy and the globes, Farriery and Medicine, Geography, Philosophy Natural or Moral, the founding of a state, civil Policy or national Negotiation, the fabulous or ancient history or of his own times, or what are to be expected in a mere political writer. The Adepts in these several ways are as apt to mistake their author as the mere Grammarian, and for the same reason, viz. because what with them is primary, is with him but secondary. Hence no wonder if like him [the grammarian] they also discover beauties never intended; nor can forgive any deviations, tho' ever so elegant, from their favourite science. ${ }^{6}$

Despite such objections many eighteenth-century readers persisted in promoting a scientific view of the poem. The term 'science,' it should be noted, was for them a more general conception than it tends to be for us

5 David R. Slavitt maintains, for example, that 'The instructional quality of the poem is only a framework' (Virgil [New Haven: Yale University Press, 1991], 48), and Sir Roger Mynors, the foremost English-language commentator on the Georgics in the twentieth century, affirms that agriculture is 'an essential element' in the poem, but adds that Virgil's engagement with his subject is as a lover of country and countryside rather than as a scientist and agriculturist: 'How much about husbandry did he already know? At least as much, no doubt, as anybody knows who has been brought up in the country, especially if his father owns land: the rules and rhythms of the countryside are part of his life, and when he sees men and women at work, he knows what they are doing, though he might be unable to do that work himself' (Virgil, Georgics: Edited with a Commentary by R. A. B. Mynors [Oxford: Clarendon Press, 1990], vi).

6 Robert Andrews, 'The Author's Preface' to Virgil, The Works of Virgil, trans. Andrews (Birmingham, 1766), 9. 
today. In its present-day acceptation, 'science' is understood to denote the systematic study of general laws that appear to underlie the physical world and its phenomena, a study known in the eighteenth century as 'natural philosophy.' In eighteenth-century usage, 'science' was a term habitually used in contradistinction to 'art': the latter term, as the late eighteenth-century agriculturist William Marshall notes, designated a skill acquired through custom, practice, and experience, whereas the former meant knowledge systematically acquired and reducible to general, theoretical principles. The artisan or mechanic becomes 'expert, thro' habit,' inadvertently, but the philosopher 'becomes wise, through design.' Accordingly, 'Art without Science is dependent on the Memory, and rests solely with Artists; Science perpetuates the Art, and transfers it, not only to distant Nations, but to future Ages. ${ }^{7}$

It is in this sense that Virgil was understood in the eighteenth century to have been a scientific writer. His poem was much more than a miscellany of rules applicable to agricultural arts: it was read as the outline of a science of husbandry. The text was understood to be systematic, grounded in an underlying theory that aims at a comprehensive understanding of the subject. As such, the Georgics was credited with transmitting the Roman science of husbandry to 'distant Nations' and 'future Ages. ${ }^{8}$ Still, those who professed to read the Georgics as science acknowledged that an unmediated encounter with the text might not yield up the knowledge they professed to find there. In their view, the situation called for informed strategies of editorial intervention to elicit the rich vein of science embedded in the text.

In the pages that follow, I should like to explore briefly how eighteenth-century poets, editors, and agriculturists turned alike to methods of textual scholarship to rescue the science of the Georgics. Their editorial interventions took two closely interconnected forms. First, as will appear, they prepared numerous new translations of the Georgics, versions that dedicated particular attention to the poem's preceptive passages, proffering translations that emphasize the poet's informed understanding of agricultural methods. Second, they pressed into service the full panoply of scholarly apparatus available to them, surrounding the poem with prefaces, footnotes and endnotes, marginal glosses, appen-

7 William Marshall, 'General Observations Concerning Scientific Agriculture,' Minutes of Agriculture; with Experiments and Observations Concerning Agriculture and the Weather (London, 1783), 2.

8 Marshall, 2. 
dices, dissertations, and indices. In their use of such apparatus they simply followed in the furrow of humanist classical scholarship, which had grown, as Anthony Grafton aptly writes, 'a thick moss' of commentary 'over the broken columns of Greek and Roman literature. ${ }^{\prime 9}$

These two modes of scholarly mediation - translation and commentary - were often deployed in tandem, with the notes and appended matter providing justification for translations and textual emendations that might be viewed as unduly tendentious or controversial. Thus, in eighteenth-century editions of the Georgics, philology is called to the aid of scientific inquiry. This mingling of methodologies, almost unthinkable today, was highly characteristic of intellectual culture in the period. The eighteenth century had not as yet given up on an ideal of the unity of the republic of letters.

An initial classificatory survey of editions is in itself highly revealing. Taking a slightly elongated view of the eighteenth century (1690-1820), one is struck, first of all, by the sheer number of translations of Virgil that appeared. The British Library holds no fewer than twenty translations of the Georgics from this period; of these, eight are separately published translations of the Georgics alone. Several of these translations, such as Dryden's, were reprinted regularly throughout the century. Also noteworthy is the fact that the brisk rate of new translations continued into the early decades of the nineteenth century, with 1808 as a kind of annus mirabilis, when three new versions appeared. Indeed, later translations show that the fascination with the Georgics as a scientific text continued into the middle of the nineteenth century.

A closer look at these editions indicates four broad, often overlapping purposes that guided the translators and editors. Literary and critical aims characterize the first group, which includes the translations of John Dryden, the earl of Lauderdale, and Joseph Trapp..$^{10}$ In the case of Dryden and Lauderdale, these are editions without extensive notes or apparatus,

9 Anthony Grafton, The Footnote: A Curious History (Cambridge, MA: Harvard University Press, 1997), 114.

10 See The Works of Virgil: Containing His Pastorals, Georgics, and Æneis, trans. John Dryden (London: Jacob Tonson, 1697); The Works of Virgil, Translated into English Verse, trans. Richard, earl of Lauderdale (London: Bernard Lintott, 1709); The Works of Virgil: Translated in English Blank Verse. With Large Explanatory Notes, and Critical Observations, trans. Joseph Trapp, 3 vols. (London, 1731); The Works of Virgil, in Latin and English, trans. Christopher Pitt and Joseph Warton (London: R. Dodsley, 1753); The Georgics of Virgil, Translated into English Blank Verse, trans. William Mills (London: Printed for the Author, 1780). 
intended as prestigious English equivalents of Virgil's iconic Latin poems. Another group of translations are those undertaken by gentlemenamateurs, often clergymen, who appear to have viewed their literary enterprise as a form of social credentialing. ${ }^{11} \mathrm{~A}$ third group are translations intended for school and student use. These are sometimes little more than cribs - the eighteenth-century equivalents of Coles or Cliffs notes. Joseph Davidson's Works of Virgil Translated into English Prose, originally published in 1743, surrounds Virgil's Latin text with an 'ordo verborum,' that is, the Latin text transposed into English word order; a literal prose translation; and 'critical, historical, geographical, and classical notes. ${ }^{12}$ Though intended to facilitate study of the poem, Davidson's edition also focuses on the inculcation of agricultural knowledge as a necessary part of a young gentleman's education.

The fourth category of translations - the primary focus of this essay - consists of those whose purpose is scientific or whose aim is to promote agricultural improvement. This group includes the translations of William Benson (1724-5), John Martyn (1741), James Hamilton (1742), William Stawell (1808), and Robert Hoblyn (1820). ${ }^{13}$ The translators and editors of these editions found ingenious ways to make Virgil's text speak with scientific authority and to transform the Roman poet into a forward-thinking eighteenth-century gentleman who, as

11 See, for example, The Georgics of Virgil, trans. Thomas Nevile (Cambridge, 1767); Virgil's Georgics, with the First, Fourth, Sixth, and Tenth Eclogues, trans. Charles Boyd (London, 1808); The Georgics of Publius Virgilius Maro, Translated into English Blank Verse, trans. James Deare (London, 1808). Nevile is identified on the title-page of his edition as 'Fellow of Jesus College, Cambridge'; and Deare is similarly introduced as 'James R. Deare, LL.B., Vicar of Bures in the County of Suffolk, and Chaplain in Ordinary to His Majesty.'

12 Works of Virgil, trans. Davidson (London, 1743), title-page. See also Virgil's Pastorals Translated into English Prose; as also his Georgicks, with such notes and reflexions as make him appear to have wrote like an excellent Farmer, trans. James Hamilton (Edinburgh, 1742); The Works of Virgil, trans. Andrews (Birmingham, 1766); The Works of Virgil: Translated into Literal English Prose; with Some Explanatory Notes, trans. Alexander (Worcester, MA, 1796).

13 See Virgil's Husbandry, or an Essay on the Georgics ... To Which Are Added the Latin Text, and Mr. Dryden's Version. With Notes Critical and Rustick, trans. Benson (London, 1724-25); Georgicorum Libri Quatuor: The Georgics of Virgil, with an English Translation and Notes, trans. Martyn (London, 1741); Virgil's Pastorals Translated into English Prose; as also his Georgicks, trans. Hamilton (Edinburgh, 1742); A Translation of the Georgics of Publius Virgilius Maro, trans. Stawell (London, 1808); A Translation of the First Book of the Georgics of Virgil, in Blank Verse; with Notes Critical and Explanatory, trans. Hoblyn (London, 1825). 
Stephen Switzer asserted, served the cause of 'Improvement in Agriculture' and excelled 'in a few Words ... all that ever wrote before or indeed since him' on the subject. ${ }^{14}$ From the work of these editors we can learn profitably about the uses of translation in the period and about the evolution of some defining generic features of academic writing, in particular, the footnote and the critical commentary.

Space does not permit a comprehensive analysis here of all these editions. But a few well-chosen examples can serve to show how textual analysis was placed in the service of scientific thought and expression. Scientific thinkers rivalled poets and critics of the period in desiring classical warrants for their inquiries, a desire that sometimes led these thinkers to borrow the latter's reading methods. Two features in particular can be singled out. The first is the extent to which those translators who seek to vindicate a scientific reading of Virgil's text are driven to construct a version of the historical Virgil who can plausibly be said to have originated the poem as they understand it. To this Virgil, who is methodical, logically rigorous, and keenly observant, and who, though genteel, was at one time in his life a practical farmer, is to be imputed the orderly treatise their editions strive to produce. By a neat circularity of argument, they further insist that the rational order the poet has imposed on his materials can be discerned only by those editors and translators who hold the requisite scientific knowledge. A second feature of these texts, seemingly contradictory of the first, is the degree to which the translators and editors rely on traditional philological and critical methods of humanistic scholarship, pioneered by men unacquainted with husbandry, to reveal the poem's consistency.

The argument that Virgil's pronouncements are systematic and logical ran counter to a widespread critical understanding in the eighteenth century of the Georgics as a poem whose distinguishing features are digressiveness and variety. In this view, the poet's characteristic procedure is to introduce a topic, such as the ploughing of land in Book 1, and then to offer a few key precepts, chosen equally for their applicability to the subject at hand and their suitability for poetic embellishment. The poet's criteria for inclusion are aesthetic as much as they are practical, if not more so. In 'An Essay on Virgil's Georgics,' widely regarded as the definitive critical statement, Joseph Addison underscores this double principle of selection as the key to Virgil's success:

14 Throughout the period the promotion of a Virgilian science of husbandry was bound up with ideological anxieties about the civic identity of the gentleman, which was held to be defined by the ownership of land. 
since this science of husbandry is of a very large extent, the poet shows his skill in singling out such precepts to proceed on as are useful and at the same time most capable of ornament. Virgil was so well acquainted with this secret that to set off his First Georgic he has run into a set of precepts which are almost foreign to his subject, in that beautiful account he gives of the signs in nature which precede the changes of the weather.

A successful georgic 'raises in our minds a pleasing variety ... whilst it teaches us,' and it relieves the tedium of 'precept upon precept' with 'beautiful and diverting digressions. ${ }^{15}$

Not so, retorts Robert Hoblyn in his early nineteenth-century edition. Hoblyn takes issue with a long tradition of scholarly annotation (by Servius, Ruaeus, and others) to insist that 'Virgil is remarkably correct in the methodical arrangement of his precepts, and in the detail of his agricultural processes.' The ignorance of critics and translators about the poet's true subject has caused them to misrepresent their author in fundamental ways. Hoblyn agrees with William Benson, who argued in 1724 that Dryden was unqualified to translate the Georgics because he knew nothing of agriculture. ${ }^{16}$

If so many 'persons of known abilities' have so repeatedly stumbled in their encounters with the Georgics, it is certainly legitimate to inquire, as Hoblyn himself concedes, 'what are the pretensions of the present Translator to superior notice?' His response typifies the justifying rationale offered by the new breed of scientific translators, who emphasize practical experience over classical learning as their primary qualification. Hoblyn maintains that 'having spent many years in the country, and attended to the practical management of a garden, and a farm, ... [and] having presumed to think for himself, without subscribing implicitly to the dictates of others, and adopting their tenets without examination,' he is now uniquely placed,

to rescue a favourite piece of a favourite author from great misrepresentation, and an oppressive load of barbarous criticism; to develope an enlightened system of husbandry founded on practical knowledge and experience, which would by no means disgrace a modern cultivator; to exhibit to view the practice

15 Joseph Addison, 'An Essay on Virgil's Georgics,' (preface to Dryden's translation), in John Dryden, The Works of John Dryden, 20 vols., ed. William Frost and Vinton A. Dearing (Berkeley and Los Angeles: University of California Press, 1987), 5: 146, 148.

16 Benson, Preface, Virgil's Husbandry, or an Essay on the Georgics: Being the Second Book Translated into English Verse (London, 1724), ii. 
of the Romans respecting the two general methods of cultivating corn, the one by the system called Novalis, which consists in "renewing" ground by alternation of fallow with subsequent fruits without manure: the other by the system called Restibus, which consisted in "perpetual tillage," by interchange of fallow crops with available fruits assisted by manure. ${ }^{17}$

Hoblyn presents himself as ideally qualified to translate the Georgics. He asserts his practical experience as a farmer, which allows him to read the poem with an informed eye, and he conducts himself in the empirical manner of the eighteenth-century natural philosopher, who subjects the 'dictates of others' to first-hand verification through observation and experiment. The second claim proves more radical than the first, for with it Hoblyn signals his readiness to adjudicate obscurities in Virgil's text in the light of modern agricultural knowledge.

A prime example of Hoblyn's procedure, signalled at the end of the passage cited above, is his reading of Virgil's advice about ploughing and cultivation in lines 63-83 of Book 1, which Hoblyn reduces to rigorous consistency. He insists that Virgil's purpose here is to lay out systematically two different methods for growing wheat: first, letting the land lie fallow every other year ('Novalis') so as to replenish its fertility without using manure (lines 63-72), and second, growing a rotation of different crops on the land ('Restibus'), so as to keep it in perpetual tillage, with the rotation of crops serving to replenish the soil (lines 73-83). Hoblyn's own metrical translation of the passage does not yield up quite the connected argument he seeks, so he supplements it with a footnote that gives, as he puts it an 'enlarged vernacular translation.' As the following illustration shows, this prose version in fact expands the text to more than twice its normal translated length, imposing analytical order on the poet's elliptical figurativeness:

But there is another method of sowing wheat in general use, and equally profitable, which remains to be considered: therefore you may chuse your alternative; and either suffer your land divested of its herbage to lie fallow in its alternate courses, and the field thus ploughed to remain inactive through rest for a determinate period: or changing the season from an autumnal to a vernal tillage, you may there sow your trimestral wheat, whence you may before have taken a crop of such of the leguminous tribe, as are known to fructify the land... . Thus also, as well as by the fallow, the ploughed fields have a sort of respite by 
the change of fruits; nor in the mean time is there no return to (or from) the inploughed land. That is (per litoten) there is a great return from the land, which has suffered the operation of being in-ploughed... . A contradistinction is manifestly intended between the two opposite systems of the novalis and the restibilis. ${ }^{18}$

A comparison with a more conventional translation shows what Hoblyn seeks to accomplish. The first part of the excerpt just cited gives his rendering of what he regards as a crucial transition in the ploughing passage, from the poet's consideration of the practice of fallowing to his discussion of continuous cultivation. The Loeb translation of the same lines (1.71-74) reads, with considerable more economy, 'In alternate seasons you will also let your fields lie fallow after reaping, and the plain idly stiffen with scurf; or beneath another star, sow yellow corn in lands whence you have first carried off the pulse that rejoices in its quivering pods. ${ }^{19}$ Hoblyn takes elaborate pains to turn Virgil's comparatively paratactic text into an elaborately hypotactic one, and he explains methodically what Virgil leaves open to inference, underscoring, for example, the value of legumes in restoring fertility to the soil. Having thus markedly expanded the original passage, he concludes, with an apparently straight face, 'These are the plain and precise instructions of Virgil, yet very poetically embellished; and contain an outline of the modes in most common use for the preparation of the wheaten tillage; and are of the most easy comprehension to any person in the least conversant with the practical management of arable land. ${ }^{20}$

The example of Hoblyn typifies the strategy of the scientific translator of Virgil, who presents himself as one agriculturist shaking hands across the centuries with his classical colleague. Any apparent obscurities in the text are to be clarified on the assumption that the Roman agriculturist, like Hoblyn himself, is systematic and orderly in the presentation of his ideas and that his agricultural knowledge in no material way contradicts the state of knowledge in modern times. But in his zeal to clinch his argument, Hoblyn ventures a step too far in his search for consistency and subjects the concluding lines of the passage on ploughing to a highly idiosyncratic reading. Most translators and commentators have as-

18 Ibid., 57-58n.

19 Virgil, Eclogues, Georgics, Aeneid I-VI, Loeb Classical Library, trans. H. Rushton Fairclough (Cambridge: Harvard University Press, 1935), 85-87.

20 Hoblyn, 58n. 
sumed that final two verses of the passage are Virgil's summary of the two modes of cultivation he has been describing: 'Thus also, with change of crop [rotations], the land finds rest, and meanwhile not thankless is the unploughed [fallow] earth' (1.82-83). ${ }^{21}$ Roger Mynors remarks, for instance, that 'both methods of maintaining fertility are summed up in the two lines as of more or less equal merit. ${ }^{22}$ But Hoblyn reads these same lines as following methodically from the preceding discussion of continuous cultivation by crop rotation. In order to gain his point he abandons scientific discussion and turns to philology instead, yet he uses the philological tradition ambivalently, simultaneously slighting the work of preceding commentators and relying heavily on their critical methods to obtain his reading.

The details of Hoblyn's discussion are too minute to be pursued here, but the upshot is a questionable instance of conjectural translation in the concluding line (1.83), as the common acceptation, 'unploughed earth,' is rewritten to read 'inploughed earth.' The new rendering is defended in a critical footnote that runs some six pages, in which Hoblyn subjects the word 'inarare' (rendered as 'unploughed' in most translations) and its immediate context to the minutest exegetical and philological scrutiny. By the time the dust settles, technical precept has been encased in a carapace of textual scholarship: 'A careful attention to etymology, to the common acceptation of the words, and to the objects of the precepts, will afford a clue to their easy solution. These two lines [1.82-83] taken together are a concluding corollary deduced from the preceding precepts, having respect to the two general methods of the Roman tillage.' Accordingly, the poet's conclusion must be read 'after this manner': "'Thus also ... the arable fields (arva) have a sort of respite by a change of fruits, and in the mean time ... there is a great return ... from the land being cultivated" (under the scheme of perpetual tillage). ${ }^{23}$

Translators before Hoblyn had complained about the obscurity of Virgil's discussion of the modes of field cultivation. Davidson's solution in his translation is to append an explanatory note that acknowledges a lack of system in the sequence of the poet's precepts:

This whole Paragraph, as it is explained by the Commentators, is so perplexed and confused, that one knows not what to make of it. The Sense of the whole

21 Virgil, Eclogues, Georgics, Aeneid I-VI, Loeb Classical Library, 87.

22 Mynors, 19.

23 Hoblyn, 74-75n. 
seems to be shortly this. The Poet, Verse 71, advises to let the Ground lie fallow every other Year; or if Circumstances will not admit of this, then he advises, Verse 73, to change the Grain, and sow, after Corn, Pulse of several kinds: But not Flax, nor Oats, nor Poppies, because, Verse 77, these burn out the Substance of the Ground. Yet these too may be used in their Turn, provided Care be taken to recruit and again enrich the Soil with fat Dung and Ashes, after it has been parched with those hot Grains, Verse 79. But he concludes, that should the Ground be left fallow, and quite untilled, instead of being sown with any of these Grains in the alternate Year, it would not be ungrateful, i.e. it would make it well worth the Farmer's While, by producing proportionately more in those Years when it is cultivated. ${ }^{24}$

But Hoblyn is more uncompromising in his pursuit of textual consistency. He rejects the commonly understood meaning of the passage in order to vindicate the presence of an ideal author, supremely rational, methodical, and clear. 'The lines themselves in their regular order,' he declares, 'exhibit the clearest proofs of practical knowledge, methodical arrangement, and illustrative perspicuity. ${ }^{25}$

Hoblyn's argument requires him to enter the lists against a weighty company of commentators, including Ascensius, Ruaeus, and Servius. For this, however, he has the precedent of Martyn, who, though mindful of his intellectual debts, declares that he 'did not depend entirely on these learned Commentators' in composing his edition and has 'often ventured to differ from them. ... They were all unacquainted with the subject, and therefore could not avoid falling into considerable and frequent errors. ${ }^{26}$ The 'scientific' editors of Virgil evince an uneasy relationship with existing literary authority. Martyn recognizes it would be foolhardy to proceed in his annotation without critical guidance, yet his instinct as a natural philosopher is to verify everything for himself. Thus, he declares, 'I am not conscious of having assumed any observation, for which I am indebted to any other. ${ }^{27}$ At play is a fundamental clash of methodological principles between two intellectual discourses (science and literary scholarship) yoked uneasily together on the printed page.

One writer who saw clearly the contradictory character of the enterprise and accordingly derided any attempt to enlist a tradition of literary Hoblyn, 76n. Martyn, xiv.

27 Ibid, $\mathrm{xv}$. 
authority in the service of science was Jethro Tull, who declares in The Horse-Hoing Husbandry, 'I beg Pardon of the Learned Writers from whom I am forc'd to differ in Opinion, as well as in Learning; I assure them 'tis unwillingly and with regret that I do. No Canon having limited what we shall think in Agriculture, nor condemned any of its Tenets for Heresy, every Man is therein a Free-Thinker, and must think according to the Dictates of his own Reason, whether he will or $n o .{ }^{28}$ Tull showed the courage of his convictions. He included in his treatise an all-out assault on Virgil's reputation as an experienced husbandman, and for his boldness he reaped an abundant harvest of abuse. ${ }^{29}$ Tull is especially scathing about a passage in Virgil immediately following the verses we have been considering, in which the poet discusses the advisability of burning stubble off the land after harvest, offering, in Lucretian poetic fashion, four speculative reasons for the efficacy of the practice (1.84-93). Tull ridicules Virgil's incoherence, declaring that 'The Reasons Virgil offers for ... Burning this barren Land are such, as abstracted from the Poetry, will appear to be utterly unbecoming the Character of a Philosopher, who pretends Rerum cognoscere Causas. His are such, that tho' contrary to one another, and Jarring among themselves, are all of them False ${ }^{30}$ Virgil's credentials as a philosopher who seeks to know the causes of things (Georgics 2.490) are undermined by his seemingly amateurish attempt at philosophic explanation.

Proponents of Virgil as an agriculturist were sensitive to Tull's attack, and their translations reflect attempts to bring coherence to the passage. Stephen Switzer, who responded directly to Tull, insisted that there is 'not the least Incoherence amongst [Virgil's reasons for burning], if apply'd to that Species or Kind of Soil, which owes its Sterility to the too close Contexture of its Parts. ${ }^{31}$ Switzer here applies criteria of textual unity and internal coherence as his tests of Virgil's accuracy. But in order to preserve coherence, Switzer finds himself compelled to qualify his argument with a crucial limiting 'if' that restricts Virgil's observation to

28 Jethro Tull, Preface, The Horse-Hoing Husbandry: or, an Essay on the Principles of Tillage and Vegetation (London, 1733), ii.

29 See Frans De Bruyn, 'Reading Virgil's Georgics as a Scientific Text: The Eighteenth-Century Debate between Jethro Tull and Stephen Switzer,' forthcoming in $E L H$.

30 Tull, 41. This remark appears in a chapter provocatively entitled, 'Remarks on the Bad Husbandry, that is so finely Express'd in Virgil's First Georgic.'

31 Stephen Switzer, preface to The Practical Husbandman and Planter 5 (August, 1733), collected in The Practical Husbandman and Planter, 2 vols. (London, 1733-4), 2: xviii-xix. 
a single set of soil conditions. Davidson attempts an opposite approach, restoring consistency to Virgil's discussion by turning it into an inventory of varying soil conditions:

Often too it has been of use to set Fire to barren Lands, and burn light Stubble in crackling Flames: Whether the Land from thence receives secret Strength and rich Nourishment, as is the Case with Land that is poor; or whether every vicious Disposition is exhaled by the Fire, and the superfluous Moisture sweats off, as it happens if the Soil be watery; or whether the Heat opens more Passages, and secret Pores, through which the Sap may be derived into the new-born Herbs, which is the Case of the stiff Clay; or whether it hardens more, and binds the gaping Veins, as happens to a spungy Soil; that the small Showers, or keen Influence of the violent Sun, or penetrating Cold of Boreas may not hurt it. ${ }^{32}$

Here the translator employs italics to indicate his prose expansions of the Virgilian text. James Hamilton uses square brackets in a similar fashion to highlight the conjectural elements of his translation and to preserve a boundary between his text and that of the poet: 'Oft too it has been gainful to set barren fields on fire, and to burn light straw [By this I mean any grass, herbs, or stalks of shrubs.] with crackling flames; [I make a difference, you see, in my version betwixt incendere and urere, because to burn ground, so as to reduce it to white ashes, causes the unctuous juices evaporate, which is detrimental. $]^{33}$

These increasingly desperate expedients expose the practical difficulties in attempts to make Virgil speak as an agriculturist. To a large degree, the translators recognize the integrity of the Virgilian text: they do not attempt, for the most part, any conjectural emendation of the original Latin. Rather, as we have seen, they shift the interpretive ground to the problem of rendering that text correctly in English. They signal the distance between their translations and the pristine original in varying ways. Besides the instances already canvassed, Benson resorts to sandwiching Virgil's Latin between his own and Dryden's translations, with all three running concurrently on the page. Martyn gives only the Latin as his main text, relegating his translation to footnotes, but then his copious notes end by quite overwhelming the original. These unwieldy expedients culminate in a significant moment of transformation, with Adam Dickson's Husbandry of the Ancients, an encyclopaedic compilation 
of classical agricultural knowledge. ${ }^{34}$ As if in recognition of the difficulty in making Virgil speak like an eighteenth-century improver, Dickson reorganizes the advice of the ancients in conformity with modern scientific expectations, dividing the subject by chapter topics (soils, kinds of crops, rotations, manuring, drainage, ploughs, and so on) that resemble the increasingly standardized format of the regional or county surveys undertaken by William Marshall, Arthur Young, and their contemporaries at the turn of the nineteenth century. Such a reorganization not only offers new modes of access to the knowledge of the ancients but also suggests new ways of thinking about it.

To conclude, these examples show the elaborate expedients eighteenth-century readers adopted in order to apotheosize the Georgics as the classic ur-text of agricultural improvement. To achieve their purpose, they applied methodologies we associate with literary scholarship and criticism to the exposition of scientific ideas. Their project ran parallel with a movement in the formal English georgic of the second half of the century towards what Juan Pellicer terms 'the unabashedly documentary emphasis' of John Dyer's The Fleece (1757) and James Grainger's The Sugar-Cane (1764). ${ }^{35}$ These poets wrote for a readership assumed to have an interest in the technical details of agricultural activity and a tolerance for an earthier view of country life, while remaining 'essentially conservative in its literary expectations. ${ }^{36}$ Gentlemanly and professional expectations thus imposed the same conflicting demands on modern experiments in georgic poetry as they did on the Virgilian prototype.

In this context, scholarly apparatus, most notably footnotes, performed a mediating function, sometimes serving, in humanist fashion, as a means of commentary and sometimes as a means of attribution of ideas or of refutation and debate. ${ }^{37}$ In Grainger's Sugar-Cane the footnote even becomes an integral generic feature of the modern formal georgic: his poetic account of the agricultural exploitation of the West Indian islands is deemed incomplete without extensive notes documenting further the topics introduced in his verses. Different modes of literary and academic discourse co-exist in Grainger's poem on the same page.

34 Adam Dickson, The Husbandry of the Ancients. In Two Volumes (Edinburgh, 1788).

35 Juan Christian Pellicer, 'The Georgic at Mid-Eighteenth Century and the Case of Dodsley's "Agriculture,"' Review of English Studies, new series, 54 (2003), 70.

36 Pellicer, 79.

37 In this sense the history of these georgic texts is an episode in the history of the footnote. See Grafton, passim. 
Most strikingly, these georgic editions, with all their impracticalities, underscore how British intellectual culture continued to rely, even as late as the early nineteenth century, on a classical authorization for its economic, social, and scientific identity. Agricultural and scientific pursuits remained deeply, if sometimes awkwardly, embedded in a larger cultural structure that gave them legitimacy, direction, and focus.

FRANS DE BRUYN

University of Ottawa 